\title{
In situ fractionation and inward migration of the solidification front in the Skaergaard intrusion, East Greenland
}

\author{
Troels F.D. Nielsen
}

For more than 80 years the Skaergaard intrusion, $68^{\circ} \mathrm{N}$ in southern East Greenland, has been a foremost natural laboratory for the study of the crystallisation and fractionation of basaltic magma. This process has been of prime importance in the evolution of the Earth and other stony planets. Models that have been developed and refined during numerous studies of this particular intrusion have been part of the foundation for petrogenetic modelling for decades. In later years, vast amounts of new data have been added, due to systematic sampling in the field and from analysis of exploration drill cores. Methods for the study on grain-size scale have advanced, and the quest for a wellsupported genetic model for the PGE-Au mineralisation of the intrusion has intensified. The new data and insight question the applicability of conventional petrogenetic modelling, and as a consequence, increasing importance is placed on in situ crystallisation and fractionation in mush zones at the roof, walls and floor of the intrusion.

\section{The Skaergaard intrusion}

The Skaergaard intrusion (Wager \& Brown 1968) is a comparatively small but well-preserved and well-exposed layered gabbro intrusion (Fig. 1A). It is 56 Ma old (Wotzlaw et al. 2012) and was emplaced during the opening of the North Atlantic. It is $7 \times 11 \mathrm{~km}$ in surface exposure, has a total structural height of $c .4 \mathrm{~km}$, and, dependent on the chosen modelling paradigm, has a box-like (Nielsen 2004) or ellipsoid shape (Irvine et al. 1998, Svennevig \& Guarnieri 2012) and a volume of $c .300 \mathrm{~km}^{3}$. The intrusion crystallised concentrically inward from the margins (Fig. 1B) with the Layered Series (LS, LZ, MZ and UZ) in the bowl-shaped floor, the Marginal Border Series (MBS) on the walls, and Upper Border Series (UBS) below the roof. The UBS and LS meet at the Sandwich horizon (SH). All three series are subdivided on the basis of a parallel evolution in liquidus parageneses (Salmonsen \& Tegner 2013 and references therein).

\section{New research initiatives}

Petrogenetic modelling of the Skaergaard gabbros and the evolution of the melt in the intrusion have traditionally rested on the textural interpretation of the gabbros as rocks composed of liquidus crystals, continued growth of these

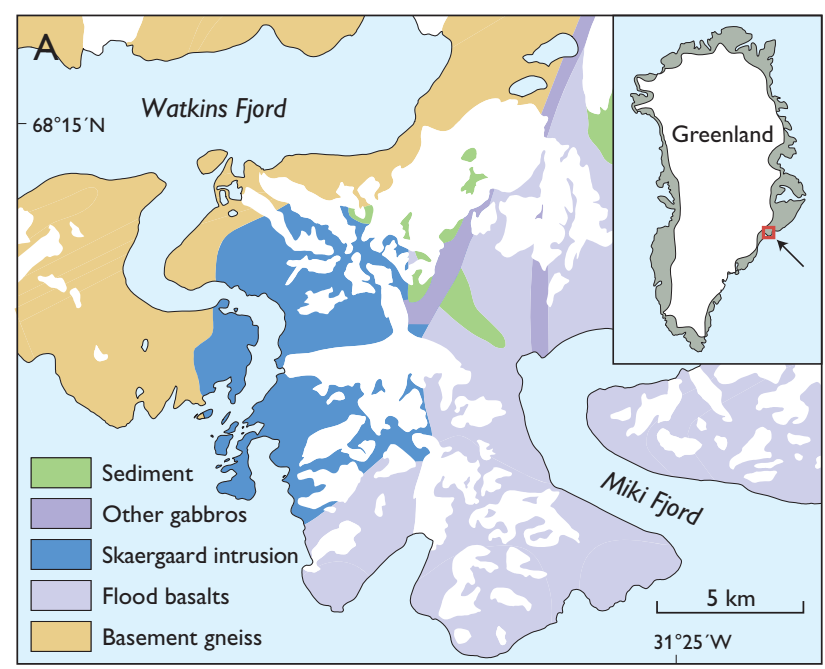

B

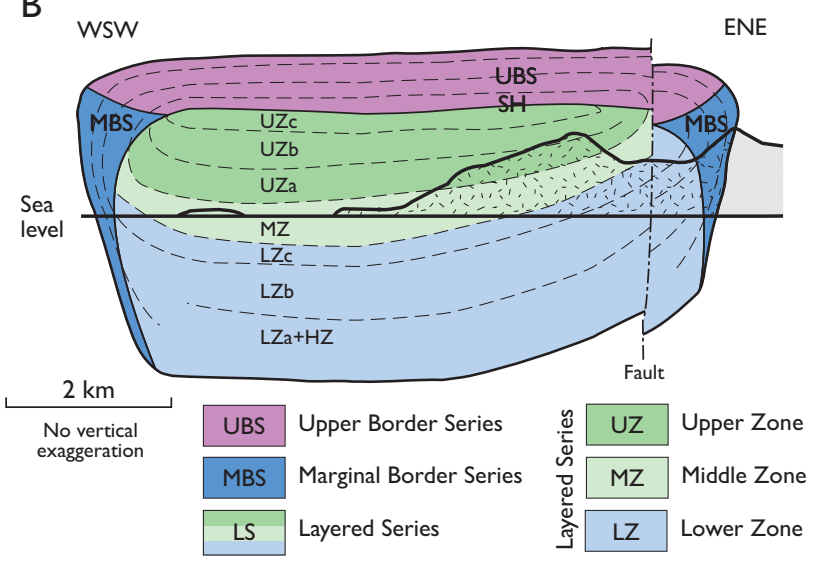

Fig. 1. A: Geological setting of the Skaergaard intrusion between basement gneisses, sediments, other gabbros and flood basalts. Location in Greenland in insert. B: Reconstructed cross-section (Nielsen et al. 2015). The Upper and Lower Zones of the Layered Series are subdivided on the basis of liquidus paragenesis (see text). Sea level and present topography are shown in black lines. 
crystals in equilibrium with the bulk liquid (adcumulus growth), and crystallisation of solids from trapped liquids. Sorting of crystals on the magma chamber floor has been likened to processes established for clastic sediments, including stratification of crystal mushes in matrix-supported mass flows. Despite challenges these models have remained robust, and most researchers are faithful to this classic cumulus paradigm and the modelling tools developed therefrom.

Research initiatives in the later decades of the 20th century (McBirney 1996 and references therein) provided much new information and were accompanied by investigations facilitated by the exploration of PGE-Au mineralisation in the intrusion (e.g. Bird et al. 1991). Notable outcomes of this research include the development of double diffusive convection models (McBirney \& Noyes 1979), evaluation of the petrogenetic importance of immiscibility between Fe-rich and Si-rich silicate melts (Jakobsen et al. 2011 and references therein), as well as evidence for isotopic disequilibrium and tight age controls on the emplacement and solidification of the intrusion (see Wotzlaw et al. 2012, and references therein).

The studies of the Skaergaard intrusion surged in 2000 with access to assay data and up to $1200 \mathrm{~m}$ long drill cores. The data in the public domain allowed calibration of structural models for the interior of the intrusion (Nielsen 2004), erection of compaction models (Tegner et al. 2009; McKenzie 2011), and studies of the mineralisation (Nielsen et al. 2005, 2015; Andersen 2006; Rudashevsky et al. 2015

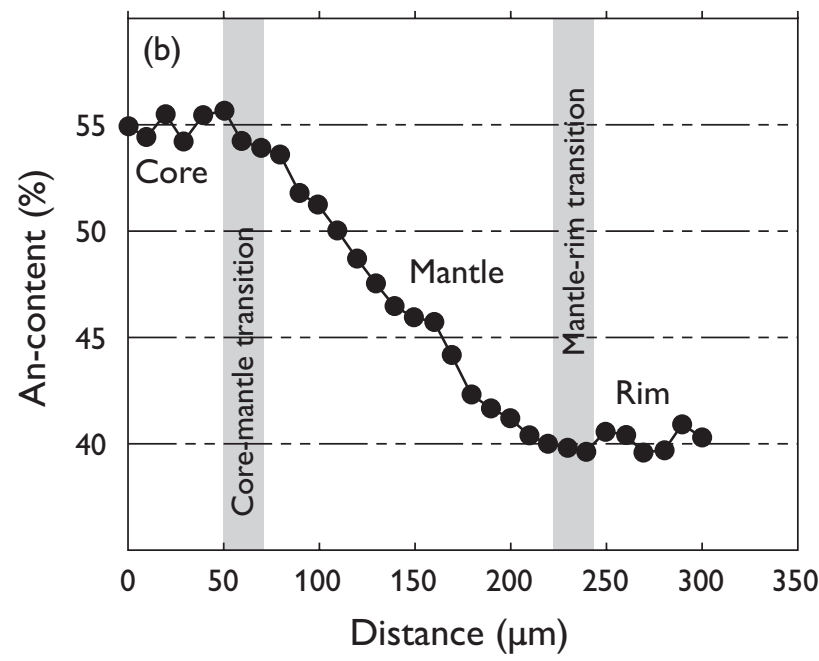

Fig. 2. Compositional variation in LZb plagioclase crystal with small core (liquidus) and broad mantle crystallised during in situ fractionation involving mush melt, and rim crystallised during buffered crystallisation (after Namur et al. 2014). and references therein; Holwell et al. 2015; Keays \& Tegner 2015). Petrographic studies focused, e.g. on compositional variations in plagioclase (Namur et al. 2014) and on clinopyroxene-filled dihedral angles between plagioclase crystals (e.g. Holness 2015 and references therein). Changes in dihedral angles give indications for, e.g. the arrival of new phases on the liquidus of the silicate melts and changes in permeability, and thus for the controls on the mobility of elements of economic interest.
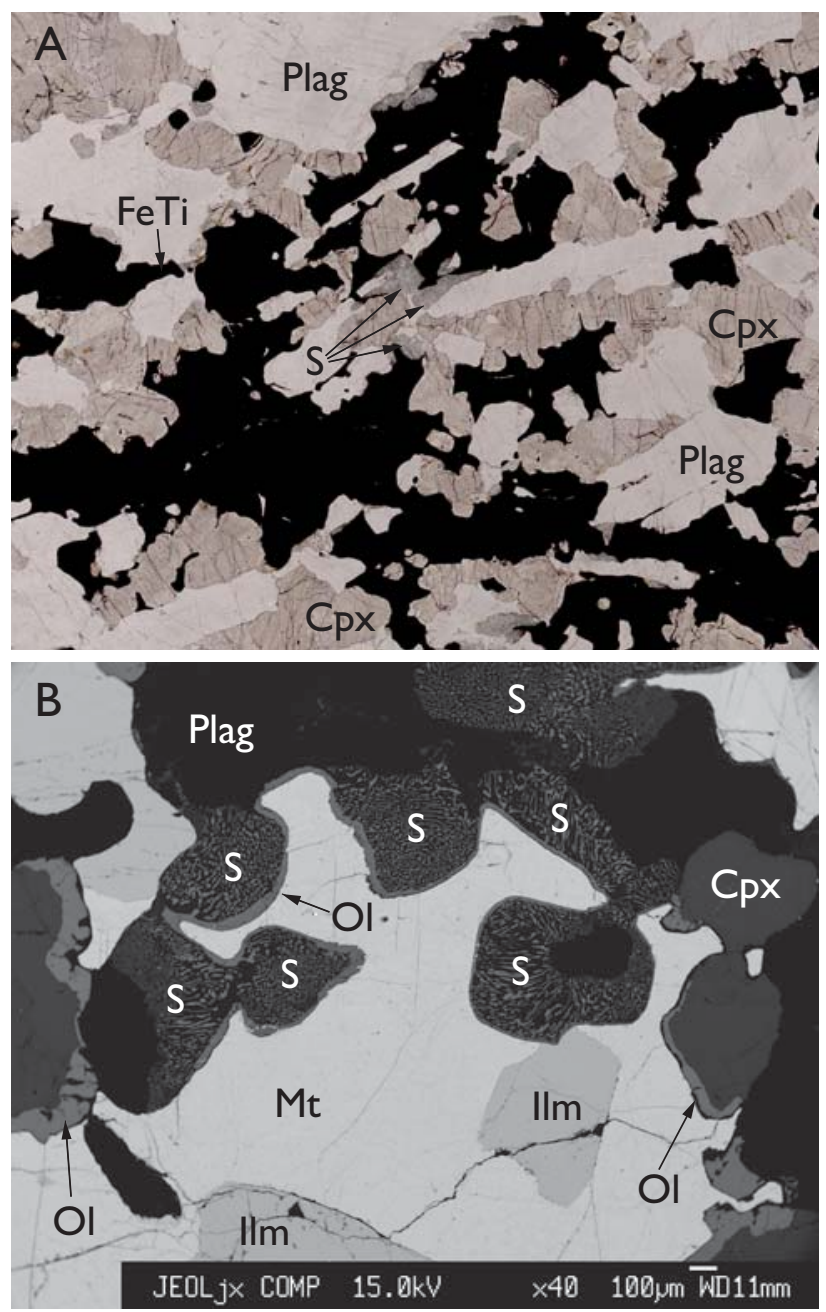

Fig. 3. A: Transmitted light image $(c .13 \times 9 \mathrm{~mm})$ showing interconnected magnetite and ilmenite that crystallised from interstitial mush melt. B: Electron microprobe backscatter image (see Nielsen et al. 2015). Symplectites $(\mathbf{S})$ formed by reaction between plagioclase and reactive Fe-rich mush melt that crystallised most of the magnetite and ilmenite in the view. Cpx: clinopyroxene (with exsolutions in Fig. 3B). FeTi: FeTi-oxides. Ilm: ilmenite. Mt: magnetite. Plag: plagioclase. Ol: olivine. S: symplectitic intergrowths. Scale at base of the image. 


\section{The importance of in situ fractionation}

Modelling based on the classic cumulate paradigm suggests that the proportion of trapped liquid decreased from 30 50 per cent to only a few per cent during the solidification of the intrusion (Tegner et al. 2009). This is, however, in conflict with reactions between liquidus minerals and Ferich silicate melts (Holness et al. 2011) and the occurrence of immiscible melt droplets throughout much of the floor cumulates (Jakobsen et al. 2011 and references therein). They are supposed to result from extended in situ crystallisation and fractionation (Langmuir 1989) in crystal mush, long residence time, and ineffective compaction. This is supported by the very common zonation in plagioclase (an example is shown in Fig. 2, Namur et al. 2014) and the distribution of magnetite crystallised from interstitial melt (Fig. 3A; Nielsen et al. 2015).

\section{Toward a new solidification model}

A magma chamber will always be hot in the middle and crystallisation will always occur in the crystal mush between solidified gabbro and the remaining melt, unless the system is affected by vigorous convection. In the Skaergaard intrusion this seems unlikely due to the concentric solidification (Nielsen 2004). All gabbro samples have recorded a temperature interval on the line of liquid descent and all have witnessed the inward migration of the crystallisation front, fronts with new phases on the liquidus of the mush liquid, and the solidification front. The mushy layer is a sub-chamber of crystal mush migrating inwards, and the samples we collect reflect only processes within the mush itself and the bulk composition of the liquid that was processed in the mush (Fig. 4).

Any sample of the gabbros is composed of minerals left behind by the inward-migrating mush layer. In broad terms, the composition of the floor gabbro is equal to bulk liquid minus what rose out of the floor, e.g., low density melt, and that of the roof gabbro is equal to what remained under the roof, e.g. low density minerals and melt (Salmonsen \& Tegner 2013; Nielsen et al. 2015). Roof and floor series are complementary, and neither series represents the evolution of the bulk magma, but their weighted average does. The modelling of the evolution of layered intrusions is commonly only based on exposed floor cumulates, and the common neglect of complementary successions in the lost roof of the intrusions may therefore lead to erroneous petrogenetic conclusions.

Undoubtedly, future research in the Skaergaard intrusion and its mineralisation will focus on very detailed petrography, mineralogy, in situ mineral chemistry and iso-

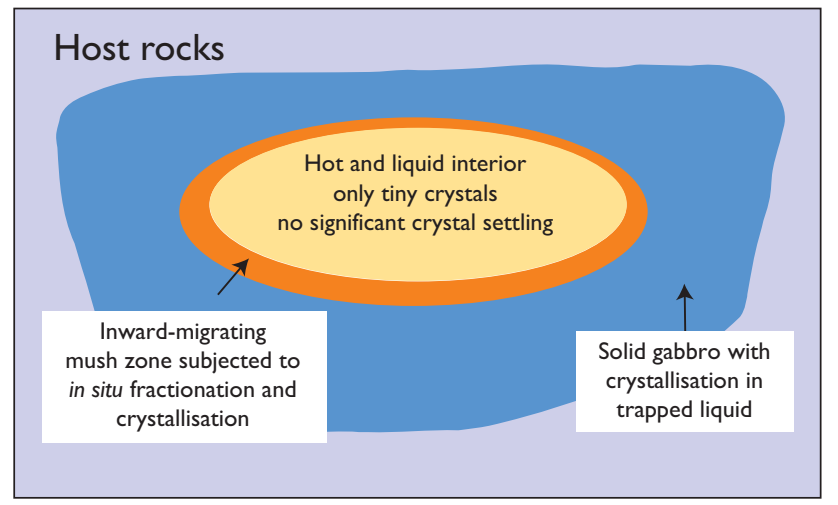

Fig. 4. Principles of the proposed model of inward migration of mush zone and liquidus front. The inward-migrating mush zone is shown in orange. The residual bulk liquid in the centre has only small and suspended crystals of liquidus phases. The remaining bulk melt is always at liquidus due to feedback from the mush zone (see Nielsen et al. 2015 for details of model).

tope geochemistry, and on unravelling of the complexities of the solidification processes. Petrogenetic modelling on the basis of bulk rock chemistry without detailed petrographic information is prone to lead to significant oversimplification and unwarranted confirmation of the chosen models.

\section{References}

Andersen, J.C.Ø. 2006: Postmagmatic sulphur loss in the Skaergaard Intrusion: Implications for the formation of the Platinova Reef. Lithos 92, 198-221.

Bird, D.K., Brooks, C.K., Gannicott, R.A. \& Turner, P.A. 1991: A goldbearing horizon in the Skaergaard Intrusion, East Greenland. Economic Geology 86, 1083-1092.

Holness, M.B. 2015: Plagioclase growth rates control three-grain junction geometry in dolerites and gabbros. Journal of Petrology 56(11), 2117-2144.

Holness, M.B., Stripp, G., Humphreys, M.C.S., Veksler, I.V., Nielsen, T.F.D. \& Tegner, C. 2011: Silicate liquid immiscibility within the crystal mush: late-stage magmatic microstructures in the Skaergaard intrusion, East Greenland. Journal of Petrology 52, 175-222.

Holwell D.A., Keays, R.R., McDonald, I. \& Williams, M.R. 2015: Extreme enrichment of Se, Te, PGE and Au in Cu sulfide microdroplets: evidence from LA-ICP-MS analysis of sulfides in the Skaergaard Intrusion, east Greenland. Contributions to Mineralogy and Petrology 170:53, http://dx.doi.org/10.1007/s00410-015-1203-y

Irvine, T.N., Andersen, J.C.Ø. \& Brooks, C.K. 1998: Included blocks (and blocks within blocks) in the Skaergaard Intrusion: geological relations and the origins of rhythmic modally graded layers. Geological Society of America Bulletin 110, 1398-1447.

Jakobsen, J.K., Veksler, I.V., Tegner, C. \& Brooks, C.K. 2011: Crystallization of the Skaergaard intrusion from an emulsion of immiscible iron- and silica-rich liquids: Evidence from melt inclusions in plagioclase. Journal of Petrology 52, 345-373.

Keays, R.R. \& Tegner, C. 2015: Magma chamber processes in the formation of the low-sulphide magmatic Au-PGE mineralization of the 
Platinova Reef in the Skaergaard intrusion, East Greenland. Journal of Petrology 56, 2319-2340.

Langmuir, C. H. 1989: Geochemical consequences of in situ crystallization. Nature 340, 199-205.

McBirney, A.R. 1996: The Skaergaard Intrusion. In: Cawthorn, R.G. (ed.): Layered Intrusions, 147-180. Amsterdam: Elsevier.

McBirney,A,R. \& Noyes, R.M. 1979: Crystallization and layering of the Skaergaard Intrusion. Journal of Petrololgy 20(3), 487-554.

McKenzie, D. 2011: Compaction and crystallization in magma chambers: towards a model of the Skaergaard Intrusion. Journal of Petrology 52(5), 905-930.

Namur, O., Humphreys, M.C.S. \& Holness, M.B. 2014: Crystallization of interstitial liquid and latent heat buffering in solidifying gabbros: Skaergaard intrusion, Greenland. Journal of Petrology 55(7), 1389-1427.

Nielsen, T.F.D. 2004: The shape and volume of the Skaergaard Intrusion, Greenland: implications for mass balance and bulk composition. Journal of Petrology 45(3), 507-530.

Nielsen, T.F.D., Andersen, J.C.Ø. \& Brooks, C.K. 2005: The Platinova Reef of the Skaergaard intrusion. In: Mungall, J.E. (ed.): Exploration for platinum-group element deposits, 431-455. MAC Short Course 35. Ottawa: Mineralogical Association of Canada.

Nielsen T.F.D., Andersen J.C.Ø., Holness, M.B., Keiding, J.K., Rudashevsky, N.S., Rudashevsky, V.N., Salmonsen, L.P., Tegner, C. \&. Veksler, I.V. 2015: The Skaergaard PGE and gold deposit: the result of in situ fractionation, sulphide saturation, and magma chamber-scale precious metal redistribution by immiscible Fe-rich melt. Journal of Petrology 56(8), 1643-1676.

Rudashevsky, N.S., Rudashevsky, V.N. \& Nielsen, T.F.D. 2015: Intermetallic compounds, copper and palladium alloys in $\mathrm{Au}-\mathrm{Pd}$ ore of the Skaergaard pluton, Greenland. Geology of Ore Deposits 57(8), 674-690.

Salmonsen, L.P. \& Tegner, C. 2013: Crystallization sequence of the Upper Border Series of the Skaergaard intrusion: revised subdivision and implications for chamber-scale magma homogeneity. Contributions to Mineralogy and Petrology 165, 1155-1171.

Svennevig, K. \& Guarnieri, P. 2012: From 3D mapping to 3D modelling: a case study from the Skaergaard intrusion, southern East Greenland. Geological Survey of Denmark and Greenland Bulletin 26, 57-60.

Tegner, C., Thy, P., Holness, M.B., Jakobsen, J.K. \& Lesher, C.E. 2009: Differentiation and compaction in the Skaergaard Intrusion. Journal of Petrology 50(5), 813-840.

Wager, L.R. \& Brown, G.M. 1968: Layered igneous rocks. Edinburgh and London: Oliver \& Boyd, 588 pp.

Wotzlaw, J.-F., Bindeman, I.N., Schaltegger, U., Brooks, C.K. \& Naslund, H.R. 2012: High-resolution insights into episodes of crystallization, hydrothermal alteration and remelting in the Skaergaard intrusive complex. Earth and Planetary Science Letters 355-356, 199-212. 